in his direction. On these points two comments may be made. First, that it was unfortunate that Sir Alfred Kitson's report on the applications for concessions now under consideration did not come within the terms of the debate. This report shows that ultimately an area of at least five thousand nine hundred square miles will be in question; and now itwouldappear that part of Kikuyu may be affected. On what terms will the development of these areas be undertaken? Secondly, a prosperity which is detrimental is illusory. The prosperity to come was contrasted by one speaker in the House with the miserable conditions of the natives to-day. But if, apart from a temporary economic crisis, the present-day conditions are in harmony with tribal traditions, a sudden accession of prosperity, for which the social organisation is not yet ready, will give rise to graver problems, similar to those now the cause of anxiety elsewhere in Africa. We are asked to trust the goodwill of those on the spot, whose relations with the native are said to be excellent. Goodwill is of little avail when question arises of interference with native custom, unless it accompanies scientific knowledge, such as can only be gained, as any anthropologist will point out, after prolonged and intensive study. Without such knowledge, modification of tribal custom always involves the danger of detriment to the social organism as a whole. Yet it is on the preservation and gradual development of that organism that the future of the native population depends.

\section{New Record for Non-Stop Flight}

A FAIREy long-range monoplane (Napier Lion engine), flown by Squadron-Leader O. R. Gayford and Flight-Lieut. G. E. Nicholetts, beat the world's longdistance non-stop flight record on February 6-8, flying from Cranwell, Lincolnshire, to Walvis Bay, 781 miles north of Cape Town. The distance of 5,340 miles was covered in 57 hours 25 minutes. The previous record was 5,012 miles from New York to Constantinople. The machine followed approximately the shortest great circle course, making detours to avoid the Atlas mountains in Northern Africa and the Ahaggar plateau in Central Sahara. The ideal weather conditions of a westerly wind at Cranwell for take off, and a following northerly wind for the rest of the journey, with clear weather and a full moon over Africa, were experienced for the first part of the journey. Later, unfavourable weather and winds over Nigeria and Duala hindered progress sufficiently to make it impossible to reach Cape Town because of lack of petrol and the approach of dusk.

As equipped for this flight the monoplane carried about $8,000 \mathrm{lb}$. of petrol and weighed about 17,000 lb. total weight. A specially prepared run-way of one mile was used at Cranwell, the machine running 1,600 yards in 58 seconds before taking off. It was fitted with an autogyroscopic control which not only relieves the pilot of the strain of continuous flying, but assists accurate course keeping. This broke down during the latter part of the flight. A short wave $(33 \cdot 71 \mathrm{~cm}$. wave-length) wireless transmitting set was used to report progress but no receiving set was carried. This gave variable results; messages were picked up over considerable distances but some were undecipherable. The flight was carried out by the Royal Air Force as part of a general policy of development of long-distance air transport for strategic purposes. Not only will the behaviour of the aircraft, engine and instruments be carefully examined, but the medical department is investigating the effects of such flights upon the personnel engaged. The special food carried was chosen by the medical authorities.

\section{John Thompson}

Charles Hutton, when engaged in editing the "Diarian Miscellany" in 1775, regretted the insufficiency of biographical material for the lives of the mathematicians responsible for the problems that appeared every year in the eighteenth century almanacks known as the "Gentleman's" and "Ladies", "Diaries", which were edited by Henry Beighton of Griff from 1714 until 1744, with the assistance of Anthony Thacker, and later by Robert Heath, 174553. One of their collaborators was John Thompson of Witherley Bridge in Leicestershire, the hundred and fiftieth anniversary of whose death falls on February 25. By good fortune his surveying instruments, until recently in the possession of his descendant, Mrs. Alkin of Atherstone, are still extant and have been presented by the Friends of the Old Ashmolean to the Lewis Evans Collection at Oxford. They show that Thompson was a practical inventor and improver of instruments as well as a mathematician. It is stated in Nichol's "History of Leicestershire" that Thompson, on leaving Atherstone School, had been intended by his father for the farming and grazing business, but the boy's innate love of mathematics was so strong that, with the collusion of his mother, he surreptitiously purchased a few mathematical books and studied them where and when he could, generally at night. He was helped by Beighton and Thacker, and contributed articles to various journals. When Atherstone common fields were enclosed in 1765, an error by the Commissioners led him to propose a prize question (No. 290) in the "Gentleman's Diary" for 1766. It had been agreed that the small cottages should have a plot known as Cottagers' Piece in the shape of two trapezia to contain 100 acres. Thompson was asked to resurvey it and found it three acres too large, on which he based his prize question, as he said, "that the error of these unmathematical Bunglers may be known".

Thompson's instruments include two levels by Thomas Wright, one dated 1724, a cross head by $J$. Search with one quadrant graduated, an early Gregorian telescope, chains, and the usual slide rules, scales and drawing instruments, and, most interesting of all, a superb plane-table and tripod designed by John Thompson himself, and inscribed "Made by G. Adams in Fleet St. London. Inst : Makr : to His Royal Highness the Prince of Wales." It is surrounded by inlaid brass scales, and measures $18 \frac{3}{4}$ in. across. 
By a special tilting arrangement the table can be adjusted at any desired angle. It is provided with marginal sights, and adjustable rules which can be raised by screws or depressed level with the surface of the board. The magnetic compass box is of the shape of a figure 8 , and the card is only graduated for $45^{\circ}$ on each side of the north-south line. It is the most perfectly designed and executed plane-table which we have seen. Two note-books show that he was instructing his sons Ralph and Samuel in the art of surveying in 1773 and 1778 respectively. Ralph Thompson also became an accomplished surveyor, and an example of his work made in 1812, a survey of the Roman town of Manduessedum on Watling Street, is reproduced in Nichols's "Leicestershire".

\section{Nest-Building of Brush-Turkeys}

An early visit to the gardens of the Zoological Society of London is recommended in order to inspect the initial stages in the nest-building of the brush-turkeys, on the north bank of the Canal. The labour of forming the vast mound of leaves, in the centre of which the eggs are laid, is performed by the male. Here they are left until they hatch by the heat generated by the fermentation. The eggs being of great size in proportion to the size of the bird, the early, 'nestling-down', stage is passed within the shell, the down being shed before hatching. By the time this takes place the birds are strong enough to force their way out, and emerge with fully developed flight-feathers. This singular phase in the infancy of birds is confined to the Megapodes, of which there are many species. But some bury the eggs in hot sand, instead of decaying vegetation. The recently added 'piping-crows' from Australia, which are more nearly related to the drongos and swallow-shrikes than to the crows, and that singular fish the climbing-perch (Anabas), are also worth a visit.

\section{Physical Nature of the Nerve Impuise}

AT the Friday evening discourse held at the Royal Institution on February 10, Prof. A. V. Hill discussed the physical nature of the nerve impulse. The properties of the nervous system are based upon a certain transmitted wave which is known as the nervous impulse. This wave, which is a few centimetres long, travels in nerve fibres of the order of $0.01 \mathrm{~mm}$. in diameter with velocities varying from a few centimetres to $100 \mathrm{~m}$. per second. Its nature is not yet understood, but it possesses certain welldefined physical characteristics. The chief difficulty in investigating it is the minuteness of the changes involved in its passage : there is, for example, a rise of temperature, but this is only of the order of one ten-millionth of a degree for each impulse, while the ohemical changes which accompany this are at present altogether beyond detection. Fortunately, owing to the development of modern electrical methods, the electrical accompaniments of the wave can be accurately recorded, and the study of the so-called 'action current' has thrown much light on the process. The nature of electrical excitation has been discussed for many years, and it seems that 'activity' isproduced when thecurrent through thenerve fibre surface exceeds a certain value at the cathode. The 'activity' seems to consist of an alteration in the physico-chemical properties of the surface layer, allowing reaction to take place momentarily between inside and outside. The change is rapidly reversed, and the nerve is then ready to transmit another impulse. The passage of the wave involves the liberation of energy during, but chiefly after, the active process. Recovery lasts 30-50 minutes and requires oxygen. In other respects, however, the nerve impulse possesses wave-like properties, and its further investigation by physical means is likely to lead to a far greater understanding of nervous processes and of the phenomena of living activity in general.

\section{Scientific Progress and Ethics}

IN the Journal of the University of Bombay (Sept. 1932), under the title "Is Man Ethically Fit for the Bounties of Science ?" Prof. D. D. Kanga of Gujarat College, Ahmedabad, comments on a convocation address by Sir C. V. Raman on the study of science. Asserting that true scholarship goes hand in hand with research, independence of thought and original thinking, Sir C. V. Raman said that the function of a university is the encouragement of the human intellect and the human spirit in their highest manifestations. The greatest value of science lies not so much in the imparting of knowledge about natural phenomena and the laws of Nature, as in the teaching of the scientific method which has served as a powerful weapon in the hands of man in the discovery of truth and has given him a new view of the universe he lives in. If the $\operatorname{sam} \theta$ method were used in the problems of daily life, whether political, industrial, social, educational, or religious, it would usher in a new era of progress and enlightenment in all the departments of life. Prof. D. D. Kanga, reviewing the sabotage which has accompanied increased productivity consequent upon the application of modern science, directs attention once more to the problem of distribution, which he reminds us is largely a matter of the individual will. It is the duty of every university to see that the advance of science and the spread of scientific culture go with a parallel advance in man's ethical and spiritual development. The motto of science should be truth and service, and the alumni of a university should be characterised alike by their ability to apply the scientific method in all problems of life and also, in Prof. Kanga's view, by their readiness to share their knowledge, wealth, power and possessions with others, of whatever race or country, for the common good.

\section{Persepolis}

THE archæological expedition to Persepolis of the Oriental Institute of the University of Chicago, one of the eleven expeditions of the Institute now at work in the East, has achieved some remarkable results in its second season's work on the site. Indeed, Dr. J. H. Breasted, director of the Institute, in a comment appended to an abstract of the report by 